\title{
Role of Oxidized Lipids in Atherosclerosis
}

\author{
Mahdi Garelnabi', \\ Srikanth Kakumanu ${ }^{1}$ and Dmitry Litvinov ${ }^{2}$ \\ ${ }^{1}$ Department of Clinical Laboratory and Nutritional Sciences, \\ School of Health and Environment, \\ University of Massachusetts Lowell, MA, \\ ${ }^{2}$ Department of Surgery, \\ The Ohio State University, Columbus, OH, \\ USA
}

\section{Introduction}

The role of oxidized lipids in cardiovascular diseases (CVD) has been investigated over the last three decades extensively. A number of studies have been carried out on the mechanisms, and pathways leading to the arterial atherosclerosis. These studies originated from the oxidation hypothesis of the atherosclerosis which was originally proposed more than 25 years ago (Steinberg et al., 1989), and since then experiments were performed by many investigators to further examine and explore the contribution of oxidation and oxidized lipids to cardiovascular diseases. Oxidized fatty acids in the ester and free forms, their decomposition products, cholesterol and its oxidized products, proteins with oxidized amino acid residues and cross-links, and polypeptides with varying extents of covalent modification with lipid oxidation products, and many others substances derived from oxidation have been the subject of detailed studies by many investigators. These products originated in vivo from oxidized lipoproteins and lipid membranes were linked to initiation and propagation of atherosclerosis (Zhang \& Salomon, 2005; Mitra et al., 2011; Hulsmans et al., 2010). The effect of dietary oxidized fat as a contributor to the oxidative stress was also investigated by several groups including our group (Catapano et al., 2000; Drüeke et al., 2001; Garelnabi et al., 2008; Mitra et al., 2011). While there is a consensus in understanding of initial oxidative steps in the generation of early fatty streak lesions as well as the role of products of peroxidized lipid decomposition such as aldehydes in atherosclerosis, the role of further oxidation into neutral carboxylic acids is still obscure. In this chapter we will review the background of the oxidation theory of lipoproteins and the current state of the knowledge. We will review and summarizes data leading to the current understanding of the role of oxidized lipids in atherosclerosis and some pathways involved in this process. We will also discuss recent studies that elucidate factors leading to oxidative stress including chemical, physical and biological factors. In addition, we will explain the current knowledge of the use of antioxidants; and explain their benefits if any to inhibit oxidation of LDL. This part will discuss in brief some selected clinical data. 


\subsection{Atherosclerosis}

Atherosclerosis is the principal contributor to the pathogenesis of myocardial and cerebral infarction, gangrene, and loss of function in the extremities. The process, which under normal circumstances is a protective response to insults against the endothelium and smooth muscle cells of arterial walls, consists of the formation of fibrofatty and fibrous lesions, and is preceded and accompanied by inflammation. The advanced lesions of atherosclerosis become pathologic, and may cause occlusion of the affected artery, result from an excessive inflammatory-fibroproliferative response to numerous different forms of insult (Ross, 1986).

The earliest recognizable lesion of atherosclerosis is the so-called 'fatty streak', an aggregation of lipid-rich macrophages and T lymphocytes within the innermost layer of the arterial wall, the intima. The ubiquity of the atherosclerotic process is attested by the finding of fatty streaks in the coronary arteries of half of the autopsy specimens from children aged 10 to 14 years (WHO, 1985). Animal observations have shown that fatty streaks precede the development of intermediate lesions, which are composed of layers of macrophages and smooth muscle cells and, in turn, develop into the more advanced, complex, occlusive lesions called fibrous plaques (Fig 1). The fibrous plaques increase in size and, by projecting into the arterial lumen, may impede the flow of blood. They are covered by a dense cap of connective tissue with embedded smooth muscle cells that usually overly a core of lipid and necrotic debris (Garelnabi, 2010).

Most of the sudden deaths from myocardial infarcts are due to ruptures or fissures, particularly in the margins of the fibrous cap where there are more macrophages, resulting in hemorrhage into the plaque, thrombosis, and occlusion of the artery (Ross, 1993). As the process continues, migrating cells reach further beneath the arterial surface, where the monocytes become macrophages, accumulate lipid, become foam cells, and together with the accompanying lymphocytes, become the fatty streak. These often form at sites of preexisting collections of intimal smooth muscle. Thereafter, continued cell influx and proliferation lead to the more advanced lesions, distinguished by their fibrous character, and ultimately to the fibrous plaque (Ross, 1993).

Studies on animals with artificially induced hypercholesterolemia have confirmed that three processes are involved in the formation of atherosclerotic lesions : (1) The proliferation of smooth muscle cells, macrophages, and possibly lymphocytes; (2) the formation of a connective tissue matrix by smooth muscle cells comprised of elastic fiber proteins, collagen, and proteoglycans; and (3) the accumulation of lipid and mostly free esterified cholesterol in the surrounding matrix and the associate cells (Daley et al., 1994).

There are numerous signals, biochemical in nature, which underlie smooth muscle proliferation. Platelet derived growth factor (PDGF), the first postulated growth factor in atherogenesis is produced by many of the cells involved in the process (i.e., platelets, macrophages, endothelial cells and smooth muscle cells). Activated macrophages can also synthesize fibroblast growth factor (FGF), endothelial derived growth factor (EDGF), and transforming growth factor beta ( $\beta$-TGF). The combination of these growth factors has been shown to be extremely potent in stimulating the migration and proliferation of fibroblasts and smooth muscle cells, as well as the formation of connective tissue element. 
When platelets interact with or adhere to sub-endothelial connective tissue, they are stimulated to release their granule contents. Endothelial cells normally prevent platelet adherence because of the non-thrombogenic character of their surface and their capacity to form antithrombotic substances (e.g., prostacyclin and heparin). When endothelium is injured, platelets are promoted to adhere to its surface and thus, the release of platelet constituents, although it is not clear that platelet adherence to modified endothelium is a common event (Ross, 1986). Several investigators have demonstrated that if platelets are absent from the site of endothelial injury, or if are prevented from the injury sites pharmacologically as in experimental models, then the intimal proliferative lesions that usually accompany such injury will not occur (Friedman et al., 1977; Haker et al., 1983). Oxidized low density lipoproteins (OxLDLs) have been shown to play a key role in the pathogenesis of atherosclerosis, since they are present in atherosclerotic lesions. Indeed, oxidized LDLs inhibit endothelium-dependent relaxation of the rabbit aorta in response to acetylcholine, as well as of porcine coronary artery in response to serotonin and platelets (Tanner et al., 1990).

\section{Oxidation of LDL}

The major constituents of plaques are lipid-laden foam cells are formed and their remains. Foam cells form when macrophages or other cells uptake an excessive amount of LDL, and die. An oxidative hypothesis of atherosclerosis was proposed in 1989 and suggested modification of LDL as a primary reason of foam cell formation and development of atherosclerosis (Steinberget al, 1989; Parthasarathy et al., 2010). A massive amount of confirming data was collected since then. It is well accepted now that oxidative processes and oxidized lipids play pivotal role in initiation and progression of the disease.

LDL is a microparticle consisting of one $A p o B$ protein molecule and a mixture of triacylglycerol, cholesterol and its esters, phospholidpids, and vitamin E. Oxidation of LDL is a gradual process starting with oxidation of vitamin $\mathrm{E}$ and polyunsaturated fatty acids. Peroxides, the primary oxidation products, undergo further transformations with generation of aldehydes among other products. Aldehydes modify amino acid residues of ApoB, primarily lysine, resulting in malondialdehyde modified ApoB (MDA-ApoB) and 4hydroxy-2-nonenal modified ApoB (4-HNE-ApoB). Biological effect of oxidized LDL varies greatly depending on the grade of oxidation. There are several terms for oxidized LDL that indicate the level of oxidation, such as MM-LDL (minimally modified LDL), fully oxidized LDL, and MDA-LDL (malondialdehyde-modified LDL). It is difficult to determine the level of oxidation in many cases. The term OxLDL (oxidized LDL) is used for any oxidized LDL regardless of the extent of oxidation.

Development of atherosclerotic lesion starts with accumulation of OxLDL in intima, the innermost part of vessel, consisting of single layer of endothelial cells that rest on basement membrane. Intimal basement membrane separates endothelial cells and smooth muscle cells in arterial blood vessels. It consists of extracellular matrix, mostly collagen and proteoglycans, with sparse immune cells and smooth muscle cells (SMC) in it.

There is detectable level of OxLDL in circulating blood, and OxLDL is observed in vascular wall. Immunoglobulin $\mathrm{M}$ (IgM) is essential for noninflamatory clearance of OxLDL by macrophages. IgM co-localizes with CD68-positive macrophages in lesions. Double 
knockout Ldlr-/- and soluble IgM-/- mice develop lesions seven time bigger than Ldlr-/control. C1qa is a complement participating in IgM-mediated clearance. There is a pronounced increase in the size of aortic root lesion in double knockout Ldlr-/-, C1qa-/mouse as compared to Ldlr-/- mouse/- (Lewis et al., 2009).

Immunization of atherosclerosis-prone Ldlr-/- mice with MDA-LDL or native LDL before feeding with cholesterol-rich atherogenic diet resulted in smaller lesion areas without significant reduction of plasma cholesterol (Freigang et al., 1998). Both type of immunization generated antibodies that recognize a wide pattern of modified and oxidized LDL likely because of some oxidation of LDL during immunization. Binding of OxLDL with antibodies demonstrated antiatherogenic effect, whether it limits the influx of OxLDL into artery wall or helps to clear retained OxLDL. Similar results were obtained in rabbit (Ameli et al., 1996).

While immunization with MDA-LDL prior or at initial stages of atherosclerosis suppresses growth of lesions in mouse and rabbit, there is a controversy in whether higher titer of antibodies to OxLDL in blood correlates with higher or lower grade of atherosclerosis (Palinski et al., 1995; Tsimikas et al., 2007, reviewed in Shoenfeld et al., 2004).

\section{Healthy artery}

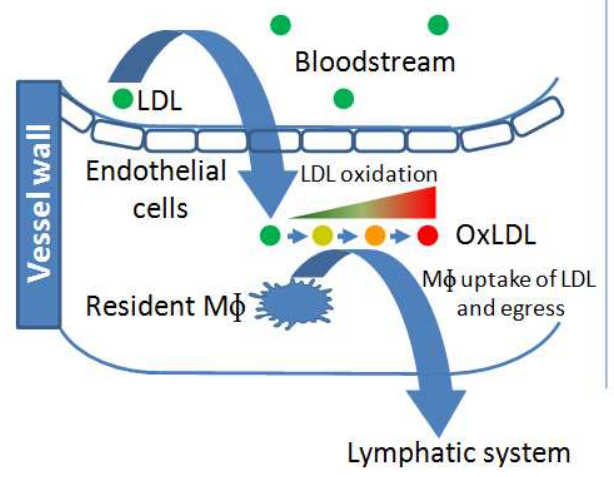

\section{Atherosclerotic artery}

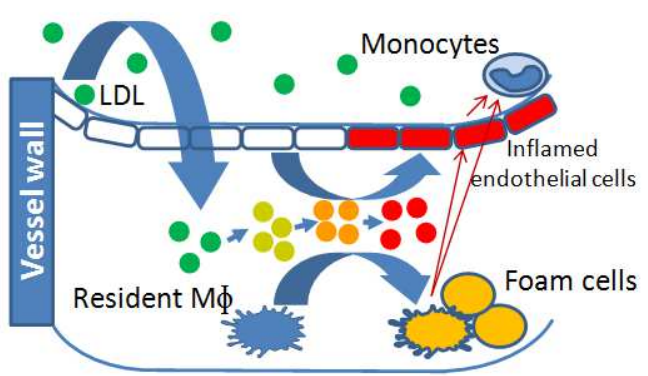

Fig. 1. OxLDL effects and fate in healthy and atherosclerotic artery wall. LDL (green circles) enter vessel wall and become gradually oxidized (depicted by changing circle color from green to red). In healthy artery tissue lymphocytes, primarily macrophages (M $\phi)$, uptake OxLDL, and egress the vessel to lymphatic system. The removal of OxLDL is impaired in atherosclerotic artery. Macrophages get overloaded with OxLDL and die generating foam cells. Overloaded macrophages release inflammatory signals that affect endothelial cells and patrolling leukocytes on the vessel surface (depicted with red arrows). Endothelial cells respond to accumulating OxLDL by inflammation as well.

Currently, the general consensus is that oxidation of LDL occurs mostly within vascular wall. Both native LDL and OxLDL are able to pass through endothelial layer passively through interendothelial junctions, or by endothelial transcytosis, an active transport process ( von Eckardstein \& Rohrer, 2009). LDL and OxLDL are retained in intima through interaction of the LDL protein ApoB-100 and proteoglycans. LDL undergoes oxidation in 
intima and becomes absorbed by macrophages through scavenger receptors. There are many scavenger receptors that vary in the substrate specificity, expression in different tissues, and biological roles. Some of them play essential role in atherosclerosis (Table 1). Excessive loading of macrophages by OxLDL convert them to dysfunctional "foam" cells. OxLDL itself or products of spontaneous or enzyme-assisted decomposition act as proinflammatory, chemotactic, growth-promoting factors (Fig 1).

\subsection{Induction of oxidative stress by OxLDL}

OxLDL are cytotoxic for all spectra of atherosclerosis-related cells: T-cells (Alcouffe et al., 1999), macrophages, endothelial cells, smooth muscle cells. OxLDL cytotoxicity in human fibroblasts is mediated through OxLDL-derived lipid peroxides and hydroperoxides, but not superoxide (Coffey et al., 1995).

High load of OxLDL induces two separate lethal processes in macrophages. The first process is activation of caspases-3 in Fas-independent manner. Other caspases, caspase-6, caspase-8, caspase-9, are likely involved as well. It ultimately leads to apoptosis with characteristic DNA fragmentation. The second process is OxLDL-induced plasma membrane lysis (necrosis) mediated by reactive oxygen species (ROS). Both processes occur concurrently, however lysis of plasma membrane is likely the actual reason for macrophages death.

Caspase activation might contribute to macrophage death, however some experiments demonstrate that the extent of the activation is not enough for OxLDL cytotoxicity, since a higher level of caspase-3 activity through activation of Fas is not lethal for macrophages. At the same time inhibitors of caspase- 3 do not suppress macrophage lysis by OxLDL, while peroxyl radical scavengers Trolox, and N,N'-diphenyl-1,4-phenylene diamine (DPPD) inhibit cytotoxicity of OxLDL. Generation of peroxyl radical as primary reactive oxygen species (ROS) in OxLDL-activated macrophages was confirmed with several specific ROS-sensitive fluorescent dyes. So, OxLDL cytotoxicity is mediated by peroxyl radicals, but not superoxide. ROS-mediated lysis and caspase activation are independent processes since inhibitors of caspase- 3 do not suppress macrophage lysis by OxLDL, and Trolox does not inhibit caspase activation when it inhibits OxLDL-induced macrophage lysis (Asmis \& Begley, 2003).

In response to OxLDL, macrophages start to generate intracellularly an increased amount of ROS. Excessive load with OxLDL and ROS generation leads to necrosis of foam cells. There are several NADPH oxidases expressed in macrophages. Nox2 (Gp91phox), a hemecontaining subunit of NADPH oxidase, is the major source of ROS during phagocytosis. Nox2 likely does not contribute to atherosclerosis, since Nox2 knockout mouse does not slow development of lesions (Kirk et al., 2000).

Nox4 is another NADPH oxidase. Protein expression of Nox4 and its binding partner p22phox in macrophages is increased by OxLDL but not by native LDL through MEK1/2 pathway. Inhibition of MEK1/2 or siRNA knockdown of Nox4 suppresses ROS production and macrophage death assessed by membrane integrity (Lee et al., 2010).

\subsection{NF-KB response to OxLDL and atherosclerosis}

$\mathrm{NF}-\mathrm{kB}$ is a family of transcription factors and their precursors sharing Rel homology domain. They function as homo or heterodimers, such as RelA/p50. In resting cells, NF-KB 
dimer is associated with IкB, an inhibitory subunit of NF-kB. There are several members in I $\mathrm{B}$ family. The canonical pathway of NF- $\mathrm{kB}$ activation is I $\mathrm{KB}$ phosphorylation by activated IKB kinase complex consisting of IKKa and IKK $\beta$ subunits and regulatory protein NEMO. Phosphorylated IкB becomes ubiquitinated and undergoes degradation. Degradation of inhibitory subunit releases NF-kB dimer, which translocates from cytoplasm to nucleus and initiates transcription of target genes. Various signals activate IKK complex including tumor necrosis factor (TNF) and interleukin-1 (IL-1). In an alternative pathway, activated NF-KB inducing kinase (NIK) phosphorylates precursor protein p100 that results in ubiquitination and proteasomal processing of a precursor protein p100 into mature p52 subunit. The subunit binds with RelB, and RelB/p52 dimer is an active transcription factor. B-cellactivating factor and other stimuli can activate NIK and thus initiate the alternative pathway. Factors such as lipopolysaccharide (LPS), CD40 ligand can activate both pathways, canonical and alternative. However, there is no data yet on regulation of NF-kB via alternative pathway in smooth muscle cells, macrophages, and endothelial cells (de Winther et al., 2005). OxLDL initiates inflammatory response in endothelial cells and leukocytes. Inflamed cells induce factors that attract leukocytes. Activation of NF-kB is one of the pathways that are involved in atherosclerosis. Activation of this pathway is observed in lesions in endothelial cells, macrophages and SMC (Brand et al., 1996).

OxLDL exerts dual effect on NF-kB activation in monocytes and macrophages. It activates NF-kB in short term, and suppresses it in long term (Brand et al., 1997; Eligini et al., 2002). Activation of NF- $\mathrm{KB}$ by OxLDL in atherosclerotic endothelial cells is more stable. An essential mechanism of NF- $\mathrm{kB}$ activation is mediated through scavenger receptor LOX-1 (lectin-like oxidized low-density lipoprotein receptor 1). Binding of OxLDL to LOX-1 induces superoxide and hydrogen peroxide generation, and NF- $\mathrm{kB}$ activation trough activation of p38 MAP kinase, PI3K, ERK1/2 pathway (Cominacini et al., 2000; Tanigawa et al., 2006). Knockdown of LOX-1 gene suppresses endothelial cell injury measured as LDH release, abates expression of MCP-1 and decreases monocyte adhesion to endothelial cells (Li \& Mehta, 2000). Knockout of LOX-1 in Ldlr-/- mouse suppresses activation of p38 MAPK, decreases NF-kB p65 protein level, and inhibits development of atherosclerosis (Mehta et al., 2007).

The importance of NF- $\mathrm{KB}$ in endothelial cells in progression of atherosclerosis is demonstrated in ApoE-/- mouse. NF-kB pathway was disrupted by ablation of $\mathrm{NEMO} / \mathrm{IKK} Y$ or expression of dominant-negative IKBa in endothelial cells. In both cases the lesions developed slower than in control ApoE-/- mouse (Gareus et al., 2008).

Inflammation is central process in development of atherosclerosis. Presentation of P-, E-, Lselectins by endothelial cells initiates vascular recruitment of circulating monocytes through selectin ligands that are expressed on surface of leukocytes, such as PSGL-1 (Yang et al., 1999; Sperandio et al., 2003). Inhibition of leukocyte recruitment slows development of atherosclerosis. Indeed, P-selectin knockout mice have smaller lesions than control animals (Dong et al., 2000). NF-kB regulates expression of P-selectin and other inflammation-related genes including E-selectin, ICAM-1, VCAM-1, and MCP-1 (Cominacini et al., 1997).

MCP-1 is another cytokine essential for development of atherosclerosis: Ldlr-/- Mcp1-/mouse has smaller lesions compare to Ldlr-/- (Gu et al., 1998). VCAM-1 on endothelial cells 
participates in tight adhesion of monocytes. VCAM-1 knockout is lethal for mouse; however a study of a transgenic mouse with suppressed expression of VCAM-1(D4D) demonstrated reduced lesion development (Cybulsky et al., 2001).

While NF-kB pathway responds to OxLDL, activation of NF-kB stimulates expression of Lox-1 and OxLDL uptake. A study of transgenic ApoE-/-, SIRT1+/- mouse with decreased SIRT1 function revealed that NF-kB inhibition decreases expression of Lox-1 and Ox-LDL uptake. SIRT1, a NAD-dependent class III deacetylases, is known to inhibit NF-kB activity by deacetylating RelA/p65. Indeed transgenic ApoE-/-, SIRT1+/- mouse has decreased SIRT1 activity an increased level of Lox-1 in aorta, and develops atherosclerosis faster compared to ApoE-/-, SIRT1+/+ mouse. Experiments with bone marrow transplantation revealed that pro-atherogenic effect of decreased SIRT1 function is mostly associated with leukocytes. ApoE-/-, SIRT1+/- peritoneal thioglycolate-elicited macrophages uptake showed increased uptake of OxLDL (Stein et al., 2010).

\section{Lipid peroxidation: NO Implication}

It is believed that lipid peroxidation is involved in the oxidative modification of low density lipoprotein (LDL) and the formation of the potent oxidant peroxynitrite (ONOO-) (Roger et al., 1994). Despite intensive research into this key step, the identity of the radical is still a mystery, especially for the in vivo situation. It may result from preformed or lipoxygenasederived lipid hydroperoxides or hydrogen peroxide, which decompose in the presence of metal ions to lipid alkoxyl radicals and lipid peroxyl radicals and to hydroxyl radical, respectively. Once formed, the carbon-centred PUFA radical reacts very quickly with molecular oxygen yielding a lipid peroxyl radical which in turn abstracts a hydrogen atom from an adjacent PUFA, yielding a lipid hydroperoxide and a new PUFA radical. It is the latter reaction that carries the lipid peroxidation chain. If no chain termination took place, a single initiating event could convert all LDL. The precise length of the chain, i.e., the number of PUFAs oxidized per one initiating radical depends on many factors especially on the antioxidants. The antioxidants of LDL compete with chain propagation by very efficiently scavenging lipid peroxyl radicals.

Lipid peroxidation can be measured in a laboratory setting by a variety of methods. Oxidized lipid extracts is measurable in spectrophotometer technique. Recent methods of analysis includes the free oxygen radicals monitor (FORM) system (Garelnabi et al, 2008), Electron Spin Resonance Spin Trapping Techniques (ESRT), and several other traditional techniques. Peroxidation of fatty acids containing three or more double bonds will produce malondialdehyde (MDA). Malondialdehyde produced by peroxidation can cause crosslinking and polymerization of membrane components (Nielsen, 1981). This can alter intrinsic membrane properties such as deformability, ion transport, enzyme activity, and the aggregation state of cell surface determinants. Because MDA is diffusible, it will also react with nitrogenous bases of DNA (Bruce \& James 1982). Increased formation of MDA has been associated with arachidonic acid metabolism and platelet aggregation (Marie, 1979; Macfarlane et al., 1977; Garelnabi et al. 2008; Garelnabi et al. 2010). Experimental studies have shown that free radicals promote platelet aggregation and thrombosis and chain breaking antioxidants, such as vitamin E, inhibit or delay arterial thrombogenesis (Ikeda et al., 1994; Jourdan et al., 1995). 


\begin{tabular}{|c|c|c|c|c|}
\hline $\begin{array}{l}\text { Scavenger } \\
\text { receptor }\end{array}$ & Expression & $\begin{array}{l}\text { LDL-related } \\
\text { substrates }\end{array}$ & Other substrates & $\begin{array}{l}\text { Effect of } \\
\text { knockout in } \\
\text { mouse }\end{array}$ \\
\hline $\begin{array}{l}\text { Class A: SR- } \\
\text { AI, SR-AII }\end{array}$ & $\begin{array}{l}\text { Tissue } \\
\text { macrophages, } \\
\text { arterial } \\
\text { endothelial } \\
\text { cells, smooth } \\
\text { muscle cells }\end{array}$ & $\begin{array}{l}\text { Acetylated LDL, } \\
\text { lower affinity for } \\
\text { OxLDL; recognize } \\
\text { modified ApoB }\end{array}$ & $\begin{array}{l}\text { Apoptotic cells, } \\
\text { beta-amyloid } \\
\text { peptide, anionic } \\
\text { phospholipids, } \\
\text { advanced glycation } \\
\text { end-products, } \\
\text { Gram-negative and } \\
\text { Gram-positive } \\
\text { pathogen-related } \\
\text { molecules }\end{array}$ & $\begin{array}{l}\text { Controversial } \\
\text { results on } \\
\text { atherosclerosis } \\
\text { development in } \\
\text { knockout of both } \\
\text { SR-AI and SR- } \\
\text { AII genes (Msr- } \\
\text { /-) in Apo-/- or } \\
\text { Ldlr-/- mice }\end{array}$ \\
\hline $\begin{array}{l}\text { Class B: } \\
\text { SR-B1 (and } \\
\text { another } \\
\text { minor splice } \\
\text { variant of the } \\
\text { same gene } \\
\text { SR-B2) }\end{array}$ & $\begin{array}{l}\text { Liver, } \\
\text { macrophages; } \\
\text { adrenal glands, } \\
\text { ovaries, and } \\
\text { testes - reverse } \\
\text { cholesterol } \\
\text { transport }\end{array}$ & OxLDL & $\begin{array}{l}\text { Native LDL, HDL, } \\
\text { apoptotic cells, } \\
\text { beta-amyloid, } \\
\text { anionic } \\
\text { phospholipids, } \\
\text { advanced glycation } \\
\text { end-products, } \\
\text { amyloid }\end{array}$ & $\begin{array}{l}\text { Srb1 knockout in } \\
\text { Apoe-/- or Ldlr- } \\
\text { /- mouse } \\
\text { promotes } \\
\text { atherosclerosis }\end{array}$ \\
\hline $\begin{array}{l}\text { Class B: } \\
\text { CD36 }\end{array}$ & $\begin{array}{l}\text { Macrophages, } \\
\text { dendritic cells, } \\
\text { endothelial } \\
\text { cells }\end{array}$ & $\begin{array}{l}\text { Moderately } \\
\text { oxidized LDL, } \\
\text { POV-PC (1- } \\
\text { palmytoyl-2-(5- } \\
\text { oxovaleryl)- } \\
\text { snglycero-3- } \\
\text { phosphocholine) ; } \\
\text { does not bind } \\
\text { acetylated LDL or } \\
\text { extensively } \\
\text { oxidized LDL }\end{array}$ & $\begin{array}{l}\text { Native LDL, HDL, } \\
\text { apoptotic cells, } \\
\text { beta-amyloid, } \\
\text { anionic } \\
\text { phospholipids, } \\
\text { advanced glycation } \\
\text { end-products, } \\
\text { thrombospondin-1, } \\
\text { collagen, fatty } \\
\text { acids, protozoan } \\
\text { and bacterial } \\
\text { peptides and } \\
\text { lipopeptides }\end{array}$ & $\begin{array}{l}\text { Knockout of } \\
\text { Cd36 in Apoe-/- } \\
\text { mouse partly } \\
\text { protects from } \\
\text { atherosclerosis }\end{array}$ \\
\hline $\begin{array}{l}\text { Class E: } \\
\text { LOX-1 }\end{array}$ & $\begin{array}{l}\text { Endothelial } \\
\text { cells, } \\
\text { macrophages, } \\
\text { SMC }\end{array}$ & OxLDL & & $\begin{array}{l}\text { Lox1 knockout } \\
\text { inhibits } \\
\text { atherosclerosis in } \\
\text { Ldlr-/- mouse } \\
\text { (Mehta et al,. } \\
\text { 2007) }\end{array}$ \\
\hline
\end{tabular}

Less studied scavenger receptors such as MARCO, SRCL (Class A), CD68 (Class D), SREC-1 (Class F), SR-PSOX/CXCL16 (Class G) are not included in the table. The table is based on review (Moore \& Freeman, 2006)

Table 1. Scavenger receptors involved in atherosclerosis 
The autoxidation of polyunsaturated lipids is an irreversible destructive process; and in tissues it may be associated with accelerated cell aging and premature cell death. Because such biological autoxidation is essentially slow process, the quantitative measurement of susceptibility to oxidation requires standard experimental stress conduction (Dildar et al., 1998).

\section{Cellular defenses against ROS}

The biochemical defenses that protect organism from the ROS include both small molecules (low molecular weight compounds such as antioxidants and free radical scavengers) and complex enzyme systems. These defenses serve to lower concentrations of free radical species such as superoxide $\left(\mathrm{O}_{2}{ }^{-}\right)$, nitric oxide $\left({ }^{\circ} \mathrm{NO}\right)$ hydroxyl radical $\left({ }^{\circ} \mathrm{OH}\right)$, lipid peroxyl radicals $\left(\mathrm{L}-\mathrm{OO}^{\circ}\right)$, and strong oxidants and precursors of free radicals such as hydrogen peroxide $\left(\mathrm{H}_{2} \mathrm{O}_{2}\right)$ and peroxynitrite $\left(\mathrm{ONOO}^{-}\right)$. If $\mathrm{ROS}$ generation exceeds defense capacity of the cell, ROS will cause excessive damage to cell components. ROS scavengers have also been used to characterize the production, nature, and toxicity of free radical species in in vitro and in vivo systems.

\subsection{Lipid soluble scavengers}

A variety of molecules that preferentially partition into membranes function by reducing lipophilic free radical species to less toxic forms. Vitamin E (a series of isomers of tocopherol) will reduce superoxide $\left(\mathrm{O}_{2}{ }^{\bullet-}\right)$, hydroxyl radical $\left({ }^{\bullet} \mathrm{OH}\right)$, singlet oxygen $\left({ }^{1} \mathrm{O}_{2}\right)$, lipid peroxy radicals, and other radical species. Ascorbate is proposed to have similar properties and may serve to maintain tocopherols in the reduced active form. Ascorbate serves as a water-soluble reductant and radical scavenger (Bruce \& James 1982). The ascorbateglutathione pathway represent an avenue through which ascorbate consumed in $\mathrm{H}_{2} \mathrm{O} 2$ reduction get recycled at the expense of NADPH. In the first step of this pathway, $\mathrm{H}_{2} \mathrm{O}_{2}$ is reduced to water by ascorbate peroxidase (APX) using ascorbate as the electron donor. The oxidized ascorbate (monodehydroascorbate) is regenerated by monodehydroascorbate; a radical and if not rapidly reduced it disproportionates into ascorbate and dehydroascorbate. Dehydroascorbate is reduced to ascorbate by dehydroascorbate reductase at the expense of GSH, yielding oxidized glutathione GSSG which is reduced by glutathione reductase (GR) using NADPH as electron donor (Fig 2), (Blokhina and Fagerstedt KV, 2010; Palma et. al, 2009; Halliwell, 2009). Enzymatic ROS scavengers: Catalase and peroxidases lower the steady state concentration of $\mathrm{H}_{2} \mathrm{O}_{2}$ which is a precursor of potent radical species. Thus, the cytotoxic potential of $\mathrm{H}_{2} \mathrm{O}_{2}$ is in large part a function of intracellular catalase and peroxidase activities that scavenge $\mathrm{H}_{2} \mathrm{O}_{2}$, and concentration of free ions of transition metals that promote generation of ${ }^{\bullet} \mathrm{OH}$ from $\mathrm{H}_{2} \mathrm{O}_{2}$. Three glutathione peroxidase (GPx; EC1.11.1.9) isozymes are known, cellular GPx, extracellular GPx, and phospholipid hydroperoxide GPx, and each contains a selenocysteine in its catalytic center. Cellular GPx; the most characterized form, can react with hydrogen peroxide and organic peroxides but not lipid hydroperoxide (Michio et al., 1995). Platelet GPx has been shown to influence the platelet arachidonic acid metabolism by stimulating lipoxygenase and inhibiting cyclooxygenase, since oxidative stress enhances the arachidonic acid metabolism and thereby creates greater demands on the regulatory systems (Malmgren et al., 1990)._Phospholipid hydroperoxide 
glutathione peroxidase (PHGPx) is an intracellular antioxidant selenoenzyme which interacts directly with peroxidized phospholipids and cholesterol and cholesteryl esters (Imai and Nakagawa 2003) . Selenium (Se) is an essential micronutrient for animals and humans that exerts its biological functions through selenoproteins. These proteins contain Se in the form of selenocysteine (Sec), Phospholipid hydroperoxide glutathione peroxidase (PHGPx or GPx4, E.C. 1.11.1.12) is characterized by the presence of selenocysteine at the active site, and belongs to the important family of glutathione peroxidases (GPx). Since the discovery of PHGPx, a number of studies have demonstrated that this seleno-enzyme is essential to organisms. However on the other hand glutaghione-S-transferase possessing glutathione peroxidase activity toward lipid peroxides, but not having selenocysteine in its active site (Ursini et al. 1982; Yagi et. al 1996)

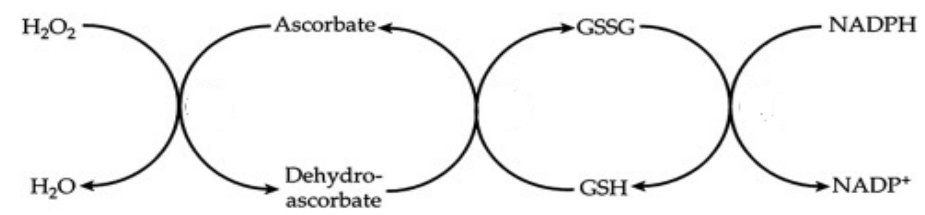

Fig. 2. The glutathione-ascorbate cycle.

Superoxide dismutases (SOD; EC 1.15.1.1) are metalloproteins that catalyze dismutation of superoxide anion radical to $\mathrm{H}_{2} \mathrm{O}_{2}$. Several types of SOD have been discovered. Mn-SOD (MW 85,000) has been found in mitochondria matrices and CuZn-SOD (MW 33,000) is contained in cellular cytosol. However, Mn-SOD and CuZn-SOD have been found also in extracellular fluids (Wesiger \& Fridovich, 1973; Marklund et al., 1982). The superoxide radical has been reported as being produced from stimulated platelets (Levine et al., 1981) but its biological value in platelet function is not clearly understood (Violi et al., 1985). A decrease in cytosolic SOD the main defense against superoxide, could lead to increased cellular peroxides. Role of diet in the activity of $\mathrm{Cu}, \mathrm{Zn}-\mathrm{SOD}$ in platelets was studied and found to be influenced by the availability of $\mathrm{Cu}$ in diet (Catherine et al., 1993). Furthermore insufficiency in dietary copper was found to increase platelet thromboxane production, which in turn significantly correlated with endogenous lipid hydroperoxides. Evidence obtained from in vitro experiments indicates that superoxide dismutase may also inhibit platelet aggregation. That is, SOD given as adjuvant therapy with thrombolysis may both blunt free radicals mediated reperfusion injury and limit the incidence of spontaneous reocclusion after restoration of blood flow (Karin \& Robert, 1993). Superoxide dismutase may protect endogenous ${ }^{\circ} \mathrm{NO}$ from inactivation by scavenging superoxide anion. In vitro the inhibitory action of ${ }^{\circ} \mathrm{NO}$ on platelet aggregation as well as their adhesion to endothelium induced by thrombin is potentiated by SOD consistent with its preventing inactivation of endothelium-derived ${ }^{\bullet} \mathrm{NO}$ (Meng et al., 1995).

Nitric oxide derived reactive nitrogen species (RNS) such as nitrogen dioxide $\left({ }^{\circ} \mathrm{NO}_{2}\right)$ and peroxynitrite $\left(\mathrm{ONOO}^{-}\right)$are indicated in the mediation of oxidative damage.Nitric oxide reacts very rapidly with oxygen radicals. Thus ${ }^{\circ} \mathrm{NO}$ reacting with $\mathrm{O}_{2}{ }^{--}$generates peroxynitrite (IUPAC-recommended name is oxoperoxonitrate $\mathrm{O}=\mathrm{N}-\mathrm{O}-\mathrm{O}^{-}$). The peroxynitrite anion $\left(\mathrm{ONOO}^{-}\right)$is relatively stable but its acid form $(\mathrm{ONOOH})$ decays to nitrite with a half life of at most $1 \mathrm{sec}$ at physiological $\mathrm{pH}$ and temperature (Ducrocq et al., 1999). Peroxynitrite mediates several of the cytotoxic effects of ${ }^{\bullet} \mathrm{NO}$ such as the destruction 
of FeS centres in enzymes. Persistent blockade of cytochrome c oxidase by ${ }^{\bullet} \mathrm{NO}$ may lead to the release of free calcium ions $\left(\mathrm{Ca}^{2+}\right)$ from the mitochondrial matrix into the cell cytosol. Nitric oxide also reacts with lipophilic peroxyl radicals, important propagating species in biological chain reaction of lipid peroxidation, to generate alkyl peroxynitrites (LOONO). These appear far more stable than $\mathrm{ONOO}^{-}$. If $\mathrm{LOONO}$ derivatives can be metabolised without the release of toxic free radicals then the reaction of ${ }^{\circ} \mathrm{NO}$ with peroxyl radicals is potentially beneficial because it allows ${ }^{\circ} \mathrm{NO}$ to stop lipid peroxidation. ${ }^{\circ} \mathrm{NO}$ inhibits platelet and phagocyte adhesion to the endothelium. However, in atherosclerotic lesions excess production of $\mathrm{O}_{2}{ }^{--}$may cause loss of the modulatory action of ${ }^{\circ} \mathrm{NO}$ and at the same time yield $\mathrm{ONOO}^{-}$which is pro-aggregatory and so could commit platelets in this environment to thrombus formation (Roger et al., 1994).

Protective mechanism: Several antioxidants can scavenge $\mathrm{ONOO}^{-}$, a molecule responsible for irreversibly oxidation of thiols to higher oxidation states, but nitrosothiols can also form, and later may act as ${ }^{\circ} \mathrm{NO}$ donors. Indeed, when isolated vascular tissues are exposed to $\mathrm{ONOO}^{-}$vasorelaxation occurs by a mechanism characteristic of release of ${ }^{*} \mathrm{NO}$ from a carrier molecule such as nitrosothiol (Liu et al., 1994). Repeated exposure to $\mathrm{ONOO}^{-}$results in a progressive decrease in the efficiency of the vasorelaxing effect.

\subsection{Benefits of antioxidants against lipid peroxidation}

There are a vast number of studies on the role of anti-oxidants particularly in the area of atherosclerosis and CVD. These studies are controversial, and do not provide clear evidences on the benefits of antioxidants for prevention or treatment of the diseases. Supplementation of antioxidant vitamins such as a-tocopherol, ascorbic acid and $\beta$-carotene used alone or in combination had long been considered to be cardio protective. However, controlled clinical trials using antioxidant vitamin supplements to prevent CVD have yielded conflicting results (Raghavamenon et al., 2009). While some secondary prevention interventions have been shown with a-tocopherol supplementation alone or in combination with ascorbic acid is reported to reduce CVD risk, other studies have shown no effect of atocopherol supplementation in both primary and secondary prevention.

Vitamin E (a-tocopherol) is found in plant oils (Honarbakshsh \& Schachter, 2009). This vitamin is extensively studied as a possible antioxidant agent against oxidation-induced cardiovascular diseases. Administration of $1000 \mathrm{IU} /$ day a-tocopherol has been shown to reduce LDL oxidation (Princen et al., 1992). A human study shown that a-tocopherol supplementation of $150 \mathrm{IU} /$ day to $1200 \mathrm{IU} /$ day increases it level in plasma and in LDL in concentration-dependent manner. In vitro oxidation of LDL was partly inhibited in LDL with higher tocopherol content (Dieber-Rotheneder et al., 1991). a-Tocopherol is reported to reduce plasma OxLDL levels at $25 \mathrm{IU} /$ day in both men and women, and the effect rises with increased supplementation until $800 \mathrm{IU} /$ day (Princen et al., 1995). Tocopherol accumulation in monocytes decreases stress-induced adhesion of monocytes to endothelial cells (Islam et al., 1998; Devraj et al., 1996; Faruqi et al., 1994; Zapolska-Downar et al., 2000), which in turn inhibit the formation of atherosclerotic lesions. Overall, a number of in vitro studies demonstrate anti-atherogenic effect of vitamin E by decreasing the production of ROS, lipid oxidation, monocyte endothelial cell adhesion and cytokines secretion. However clinical studies have not revealed anti-atherogenic effect in human (Yusuf et al., 2000). 
Vitamin C (ascorbic acid) is principally found in citrus fruits, broccoli, red pepper, and cauliflowers, etc. Ascorbate acts in combination with vitamin $\mathrm{E}$ and beta-carotene to protect them from excretion and recycle them for further use. It is also reported to inhibit OxLDL formation indirectly by protecting vitamin E and beta-carotene (Jialal \& Grundy, 1991; Kagan et al., 1992). Apart from this vitamin C is reported to inhibit endothelial apoptosis initiated by inflammatory cytokines in vitro, and reduces circulating apoptotic microparticles in human (Rössig et al., 2001). Adhesion proteins such as ICAM-1 can be involved in atherosclerosis. Ascorbate supplementation of subjects with low baseline level of this vitamin suppresses mRNA and protein expression of ICAM-1 in monocytes (Rayment et al, 2003). While these and other studies suggest that vitamin C might have antiatherogenic effect, there is no conclusive clinical evidence of such effect.

$\beta$-Carotene is indicated in preventing oxidation of lipids which might decrease atherosclerotic lesions formation. $\beta$-Carotene is proposed to be efficient scavenger of singlet oxygen and it attenuates oxidative stress, however it does not directly inhibit lipid peroxidation (Briviba et al., 2004).

Polyphenols are another group of antioxidants which are abundant in vegetables and fruits and are found to reduce the risk of CVD (Naderi et al., 2003). They contain both hydrophilic and hydrophobic moieties (Woodman \& Chan, 2004). Polyphenols are suggested to inhibit lipid peroxidation (Madrau et al, 2009). It has also been reported that flavonoids chelates copper and iron ions, rendering them inactive to participate in free radical generating reactions (Fernandez et al., 2002). Polyphenols are also known to inhibit enzymes responsible for generation of ROS such as NADPH oxidase, lipoxygenase, phospholipase A2, and xanthine oxidase (Rice-Evans et al., 1997). Indirectly inhibiting the formation of OxLDL, the benefits of flavonoids goes beyond the protection against LDL oxidation to protect the HDL-associated paraoxonase activity (Patel et al., 2007). The antiatherogenic effect of mulberry leaf extracts (MLE) and the polyphenolic extracts (MLPE), which contain polyphenols including quercetin $(11.70 \%)$, naringenin $(9.01 \%)$ and gallocatechin gallate $(10.02 \%)$ was studied by Yang et al. 2011. Both MLE and MLPE inhibited the oxidation and lipid peroxidation of LDL, while MLPE was shown to be more potent.

\section{Clinical studies: OxLDL and antioxidants}

A number of studies have demonstrated an association of circulating OxLDL with atherosclerosis disease (Itabe \& Ueda, 2007; Hulthe \& Fagerberg, 2002). The size of LDL particles might have an effect on LDL oxidation. Smaller LDL was associated with higher level of OxLDL. However the association was observed in diabetic subjects, but not in nondiabetic subjects (Scheffer et al., 2003).

OxLDL level normalized to LDL or ApoB protein levels was increased in diabetic subject with macrovascular diseases compared to diabetic subjects without such diseases. Increased OxLDL normalized level was associated with TT genotype of 108C/T polymorphism in PON1 promoter with lower level of expression of the gene (Tsuzura et al., 2004; Brinkley et al., 2009) have demonstrated for the first time that plasma OxLDL levels are related to arterial stiffness in elderly men and women; suggesting that the oxidative modification of LDL may be associated with changes in the elastic properties of blood vessels. Their findings suggest that 
while antioxidant supplementation trials have been found to be largely ineffective in preventing cardiovascular outcomes, other interventions including aerobic exercise training and pharmacological treatment with lipid and blood pressure-lowering medications may have significant antioxidant effects that are related to reductions in CVD risk. Another study have shown that oxidized lipoprotein(a) is significantly correlated with blood glucose level among healthy young women, suggesting that lipoprotein(a) may be oxidized with increased glucose concentration even within the normal glucose level (Kotani et al., 2010).

There is some controversy on the role of antioxidants on development of atherosclerosis. A number of clinical studies have demonstrated an anti-atherosclerotic effect of antioxidants while a group of other studies do not see any appreciable benefit of the use of antioxidants. The following are examples of these studies that have suggested an inhibiting effect of antioxidants on lesion development. Gey \& Puska (1989) have reported that vitamin E and A concentrations in the plasma were inversely proportional to cardiovascular risks. A study of 667 cases of atherosclerosis-induced coronary disease developed in originally healthy (not diagnosed with coronary heart disease, diabetes, or hypercholesterolemia) 39,910 US men have shown a protective effect of vitamin E but not vitamin C. Carotene appeared to be protective in non-smoking men, however increased the risk of coronary disease among smokers (Rimm et al., 1993). A protective effect of vitamin E was observed in similar study of 87,245 women developed 552 cases of major coronary disease in eight years (Stampher et al., 1993).

However a large the Heart Outcomes Prevention Evaluation (HOPE) study did not show any anti-atherogenic effect of vitamin E (Yusuf et al., 2000). Subjects who were taking vitamin $\mathrm{E}$ and placebo developed atherosclerosis-related diseases such as myocardial infarction, stroke, unstable angina, congestive heart failure at the same rate. Potential explanation for the failure of antioxidants in clinical studies may include the type of dose, duration, time of introduction, i.e. stages of the disease at which the treatment/supplementation were introduced and the selection of an optimal doses of antioxidants. Also, most of the studies did not measure the oxidative stress markers in the plasma to take it into account (Parthasarathy et al., 2001).

Research has provided strong evidence that LDL oxidation plays an important role in the pathogenesis of atherosclerosis and cardiovascular diseases. The involvement of lipid peroxidation in the propagation of the disease is well supported by clinical and scientific research using cell culture and animal models; these studies clearly point that modification of the LDL and the accompanied oxidative damage trigger an inflammation response that mediate the development of the atherosclerosis. One may assume that antioxidants should inhibit the oxidative damage and slow the inflammation processes that lead to CVD and associated with metabolic disorders. However despite of some positive findings, antioxidant compounds did not consistently prove to be potent protective agents against atherosclerosis. In animal atherosclerosis, which is studied in the short term, the emphasis is on establishing the lesions. Thus, antioxidants, such as a-tocopherol, might affect predominantly the initial formation and progression of the lesion. In humans, particularly in those who already have clinically significant events, the early steps might have already occurred. In such cases, atocopherol and similar antioxidants could affect the conversion of aldehydes into carboxylic 
acids. The latter, are presumed to be nonatherogenic and are easily degraded via fatty-acid degradation pathways (Raghavamenon et al., 2009). Based on these arguments it may be necessary for the scientific community to revisit the topic and investigate in well structured studies the type, dose, duration of the anitoxidants on a well defined population of subjects with various stages of CVD and its associated metabolic disorders such as diabetes, obesity and hyperlipidemia.

\begin{tabular}{|c|c|c|}
\hline Anti-oxidants & Mechanism & References \\
\hline$\beta$-carotene & $\begin{array}{l}\text { Scavenging ROS and excellent } \\
\text { trapper of singlet oxygen, acts } \\
\text { against LDL oxidation }\end{array}$ & $\begin{array}{l}\text { Honarbakshsh \& Schachter, } 2009 . \\
\text { Princen et al., } 1992\end{array}$ \\
\hline Vitamin C & $\begin{array}{l}\text { Scavenging ROS, reactivating } \\
\text { other anti-oxidants such as } \\
\text { Vitamin E; inhibit formation } \\
\text { of OxLDL, Il-1 } \beta \text { secretion or } \\
\text { chemokines and monocyte - } \\
\text { endothelial cell adhesion and } \\
\beta \text {-carotene which are anti- } \\
\text { atherogenic }\end{array}$ & $\begin{array}{l}\text { Dunstan et al., } 2007 \\
\text { Honarbakshsh \& Schachter, } 2009 . \\
\text { Jialal \& Grundy, } 1991 . \\
\text { Kagan et al, } 1992 . \\
\text { Rössig et al, } 2001 . \\
\text { Gokce et al., 1999, } \\
\text { Rayment et al., } 2003 . \\
\text { Heller et al., 1999 }\end{array}$ \\
\hline Vitamin E & $\begin{array}{l}\text { Scavenging ROS, reported to } \\
\text { inhibit formation of OxLDL, } \\
\text { Il- } 1 \beta \text { secretion or chemokines } \\
\text { and monocyte -endothelial } \\
\text { cell adhesion }\end{array}$ & $\begin{array}{l}\text { Dunstan et al., } 2007 \\
\text { Honarbakshsh \& Schachter, } 2009 . \\
\text { Princen et al., } 1992 . \\
\text { Islam et al., } 1998 . \\
\text { Devraj et al., } 1996 . \\
\text { Faruqi et al, } 1994 . \\
\text { Zapolska-Downar et al., } 2000\end{array}$ \\
\hline Selenium & $\begin{array}{l}\text { Cofactor for glutathione } \\
\text { peroxidase. Has antioxidant } \\
\text { capacity. }\end{array}$ & Michiels et al., 1994 \\
\hline Zinc & $\begin{array}{l}\text { Cofactor for superoxide } \\
\text { dismutase. Protects cells from } \\
\text { oxidative damage. }\end{array}$ & Michiels et.al., 1994 \\
\hline Curcumin & $\begin{array}{l}\text { Chelating of iron and copper } \\
\text { ions, scavenging of ROS, } \\
\text { inhibiting lipid peroxidation } \\
\text { Protects anti-oxidant } \\
\text { enzymes. }\end{array}$ & $\begin{array}{l}\text { Wongcharoen \& Phrommintikul, } \\
2009\end{array}$ \\
\hline Quercetin & $\begin{array}{l}\text { Scavenging of metals ions, } \\
\text { and inhibition ROS. } \\
\text { Activation of NF-kB, which is } \\
\text { involved in development of } \\
\text { atherosclerosis. }\end{array}$ & Cho et al., 2003 \\
\hline Resevetrol & $\begin{array}{l}\text { Inhibits ROS production and } \\
\text { lipid peroxidation }\end{array}$ & Ramprasath \& Jones, 2010 \\
\hline Ergothioneine & $\begin{array}{l}\text { Protects endothelial cells from } \\
\text { oxidative damage by reactive } \\
\text { nitrogen species. }\end{array}$ & Martin, 2010 \\
\hline
\end{tabular}

The table describes the currently investigated antioxidants and their relation to markers of CVD.

Table 2. Role of Antioxidants in Cardiovascular Disease 


\begin{tabular}{|c|c|c|c|}
\hline Clinical study & Findings & No of patients & References \\
\hline $\begin{array}{l}\text { Department of } \\
\text { Internal Medicine, } \\
\text { Kochi Medical } \\
\text { School, Kochi, Japan. }\end{array}$ & $\begin{array}{l}\text { OxLDL increased in subjects with } \\
\text { PON1 genotype that lead to } \\
\text { decreased expression of PON1 } \\
\text { protein }\end{array}$ & 155 & Tsuzura et al., 2004 \\
\hline AIR study & $\begin{array}{l}\text { OxLDL role in atherosclerosis and } \\
\text { inflammation }\end{array}$ & 391 & $\begin{array}{l}\text { Hulthe \& Fagerberg, } \\
2002\end{array}$ \\
\hline CARDIA study & $\begin{array}{l}\text { OxLDL indication metabolic } \\
\text { syndrome and in abdominal } \\
\text { obesity, hyperglycemia and } \\
\text { hypertriglyceridemia }\end{array}$ & 1889 & Holvoet et al., 2008 \\
\hline \begin{tabular}{|l|} 
Metabolic \\
Laboratory, \\
Department of \\
Clinical \\
Chemistry study, \\
Netherlands
\end{tabular} & $\begin{array}{l}\text { Smaller LDL are associated with } \\
\text { higher level of OxLDL }\end{array}$ & 116 & Scheffer et al., 2003 \\
\hline HOPE Study & $\begin{array}{l}\text { No effect of vitamin E on } \\
\text { development of CVD }\end{array}$ & 9541 & Yusuf et al., 2000 \\
\hline
\end{tabular}

Table summarizes some clinical studies measured OxLDL in plasma

Table 3. Clinical studies on OxLDL

\section{Conclusions and perspectives}

The low density lipoprotein oxidation hypothesis is pivotal to the explanation of the formation of fatty streak lesions. A wide range of atherogenic processes has been reported to be influenced by OxLDL and its components. The presence of OxLDL in lesions and plasma of patients with various forms of coronary artery diseases and other related metabolic disorder confirms the role of oxidized lipids in atherosclerosis. This conclusion led to numerous studies on the role of antioxidants in the prevention or treatment of atherosclerosis. However they did not yield uniformed outcome on the role of antioxidants in suppressing of the atherosclerotic process. Possible reasons might include discrepancies in experimental models, study designs, and schemes of treatment. Results shown in cell culture or animal models do not necessarily translate to similar results in human due to the major difference between the atherosclerosis development and stages in the animal models and human. Another factor that has not been tested yet is a possible inhibition of oxidation of OxLDL-released aldehydes by antioxidants. If oxidation of aldehydes is inhibited, they modify proteins and cause wide spectra of biological effects that exaggerate atherosclerotic processes. The future studies on the role of antioxidants in atherosclerosis should take in consideration these factors.

\section{References}

Alcouffe J, Caspar-Bauguil S, Garcia V, Salvayre R, Thomsen M, Benoist H. (1999). Oxidized low density lipoproteins induce apoptosis in PHA-activated peripheral blood mononuclear cells and in the Jurkat T-cell line. J Lipid Res.;40(7):1200-10.

Ameli S, Hultgårdh-Nilsson A, Regnström J, Calara F, Yano J, Cercek B, Shah PK, Nilsson J. (1996). Effect of immunization with homologous LDL and oxidized LDL on early 
atherosclerosis in hypercholesterolemic rabbits. Arterioscler Thromb Vasc Biol.;16(8):1074-9.

Asmis R, Begley JG. (2003). Oxidized LDL promotes peroxide-mediated mitochondrial dysfunction and cell death in human macrophages: a caspase-3-independent pathway. Circ Res. 10;92(1):e20-9

Blokhina O, Fagerstedt KV (2010). Reactive oxygen species and nitric oxide in plant mitochondria: origin and redundant regulatory systems. Physiol Plant. Apr;138(4):447-62.

Brand K, Eisele T, Kreusel U, Page M, Page S, Haas M, Gerling A, Kaltschmidt C, Neumann FJ, Mackman N, Baeurele PA, Walli AK, Neumeier D. (1997). Dysregulation of monocytic nuclear factor-kappa B by oxidized low-density lipoprotein. Arterioscler Thromb Vasc Biol.; 17: 1901-1909.

Brand K, Page S, Rogler G, Bartsch A, Brandl R, Knuechel R, Page M, Kaltschmidt C, Baeuerle PA, Neumeier D. (1996). Activated transcription factor nuclear factorkappa B is present in the atherosclerotic lesion. J Clin Invest.;97(7):1715-22.

Brinkley TE, Nicklas BJ, Kanaya AM, Satterfield S, Lakatta EG, Simonsick EM, SuttonTyrrell K, Kritchevsky SB. (2009).Plasma oxidized low-density lipoprotein levels and arterial stiffness in older adults: the health, aging, and body composition study. Hypertension.;53(5):846-52

Briviba K, Schnäbele K, Rechkemmer G, Bub A (2004). Supplementation of a diet low in carotenoids with tomato or carrot juice does not affect lipid peroxidation in plasma and feces of healthy men. J Nutr.; 134(5):1081-3.

Bruce, A.F., James D.C. (1982). Biology of disease. Free radicals and tissue injury. J. Lab. Invest., 47: 412-426.

Catapano AL, Maggi FM, Tragni E. (2000). Low density lipoprotein oxidation, antioxidants, and atherosclerosis. Curr Opin Cardiol.;15(5):355-63

Catherine, M., Kenneth, D., Malvin, M. (1993). Thromboxane production in copper-deficient and marginal platelets: Influence of superoxide and lipid hydroperoxides. P.S.E.BM., 202: 167-173.

Cho SY, Park SJ, Kwon MJ, Jeong TS, Bok SH, Choi WY, Jeong WI, Ryu SY, Do SH, Lee CS, Song JC, Jeong KS. (2003). Quercetin suppresses proinflammatory cytokines production through MAP kinases and NF-kappa B pathway in lipopolysaccharidestimulated macrophage. Mol Cell Biochem. 243(1-2):153-60.

Coffey MD, Cole RA, Colles SM, Chisolm GM. (1995). In vitro cell injury by oxidized low density lipoprotein involves lipid hydroperoxide-induced formation of alkoxyl, lipid, and peroxyl radicals. J Clin Invest. 96: 1866-1873.

Cominacini L, Garbin U, Fratta Pasini A, Paulon T, Davoli A, Campagnola M, Marchi E, Pastorino AM, Gaviraghi G, Lo Cascio V. (1997). Lacidipine inhibits the activation of the transcription factor NF-kappaB and the expression of adhesion molecules induced by pro-oxidant signals on endothelial cells. J Hypertens.;15(12 Pt 2):1633-40.

Cominacini L, Pasini AF, Garbin U, Davoli A, Tosetti ML, Campagnola M, Rigoni A, Pastorino AM, Lo Cascio V, Sawamura T. (2000). Oxidized low density lipoprotein (OxLDL) binding to OxLDL receptor-1 in endothelial cells induces the activation of NF-kappaB through an increased production of intracellular reactive oxygen species. J Biol Chem.;275(17):12633-8.

Cybulsky MI, Iiyama K, Li H, Zhu S, Chen M, liyama M, Davis V, Gutierrez-Ramos JC, Connelly PW, Milstone DS. (2001). A major role for VCAM-1, but not ICAM-1, in early atherosclerosis. J Clin Invest. ;107(10):1255-62. 
Daley, S., Klemp, K., Guyton, J., Rogers, K. (1994). Cholesterol-fed and Casein-fed rabbit models of atherosclerosis. Part 2 : Differing morphological severity of atherogenesis despite matched plasma cholesterol levels. Arterioscler. Thromb., 14: 105-114.

Darley-Usmar V, Wiseman H, Halliwell B. (1995) Nitric oxide and oxygen radicals: a question of balance. FEBS Lett.; 369(2-3):131-5.

de Winther MP, Kanters E, Kraal G, Hofker MH. (2005). Nuclear factor kappaB signaling in atherogenesis. Arterioscler Thromb Vasc Biol.;25(5):904-14.

del Río LA, Corpas FJ, Sandalio LM, Palma JM, Barroso JB (2003). Plant peroxisomes reactive oxygen metabolism and nitric oxide. IUBMB Life. Feb;55(2):71-81.

DeMaio S, King SB, Lembo NJ, Roubin GS, Hearn JA, Bhagavan HN, Sgoutas DS. (1992). Vitamin E supplementation, plasma lipids and incidence of restenosis after percutaneous transluminal coronary angioplasty (PTCA). J Am Coll Nutr, 11:68-73.

Devraj S, Li D \& Jialal I (1996). The effects of alpha tocopherol supplementation on monocyte function. Decreased lipid oxidation, interleukin 1 beta secretion, and monocyte adhesion to endothelium. J Clin Invest. 98(3): 756-763.

Dieber-Rotheneder M, Puhl H, Waeg G, Striegl G, Esterbauer H. (1991). Effect of oral supplementation with D-alpha-tocopherol on the vitamin E content of human low density lipoproteins and resistance to oxidation. J Lipid Res.;32(8):1325-32.

Dildar Konukglu, Tulay Akcay, Tijen Erdem (1998). Susceptibility of erythrocyte lipid to oxidation and erythrocyte antioxidant status in myocardial infarction. Clini. Biochem., 31: 667-671.

Dong ZM, Brown AA, Wagner DD. (2000). Prominent role of P-selectin in the development of advanced atherosclerosis in ApoE-deficient mice. Circulation. ;101(19):2290-5.

Drüeke TB, Nguyen Khoa T, Massy ZA, Witko-Sarsat V, Lacour B, Descamps-Latscha B. (2001). Role of oxidized low-density lipoprotein in the atherosclerosis of uremia. Kidney Int Suppl.;78:S114-9.

Ducrocq, C., Blanchard, B., Pignatelli, B., Ohshima, H. (1999). Peroxynitrite: an endogenous oxidizing and nitrating agent. CMLS, 55: 1068-1077.

Dunstan JA, Breckler L, Hale J, Lehmann H, Franklin P, Lyons G, Ching SY, Mori TA, Barden A, Prescott SL. (2007). Supplementation with vitamins C, E, b-carotene and selenium has no effect on anti-oxidant status and immune responses in allergic adults: a randomized controlled trial. Clin Exp Allergy.37(2):180-7.

Eligini S, Brambilla M, Banfi C, Camera M, Sironi L, Barbieri SS, Auwerx J, Tremoli E. (2002). Colli S. Oxidized phospholipids inhibit cyclooxygenase-2 in human macrophages via nuclear factor-kappaB/IkappaB-and ERK2-dependent mechanisms. Cardiovasc Res; 55: 406-415.

Faruqi R, de la Motte C \& DiCorleto PE (1994). Alpha-tocopherol inhibits agonist-induced monocytic cell adhesion to cultured human endothelial cells. J Clin Invest ;94,592-600.

Fernandez MT, Mira ML, Florêncio MH and Jennings KR.(2002). Iron and copper chelation by flavonoids: an electrospray mass spectrometry study. J Inorg Biochem.92(2):105-11.

Freigang S, Hörkkö S, Miller E, Witztum JL, Palinski W. (1998). Immunization of LDL receptor-deficient mice with homologous malondialdehyde-modified and native LDL reduces progression of atherosclerosis by mechanisms other than induction of high titers of antibodies to oxidative neoepitopes. Arterioscler Thromb Vasc Biol.;18(12):1972-82.

Friedman, J., Stemerman, B., Wenz, B., et al., (1977). The effect of thrombocytopenia on experimental arteriosclerotic lesion formation in rabbits: Smooth muscle cell proliferation and re-endothelization. J. Clin. Invest., 60: 1191-1201. 
Garelnabi M, Brown WV, Le NA. (2008). Evaluation of a novel colorimetric assay for free oxygen radicals as marker of oxidative stress. Clin Biochem.;41(14-15):1250-4.

Garelnabi M, Gupta V, Mallika V, Bhattacharjee J. (2010). Platelets oxidative stress in Indian patients with ischemic heart disease. J Clin Lab Anal. 24(1):49-54.

Garelnabi M. (2010). Emerging Evidences from the Contribution of the Traditional and New Risk Factors to the Atherosclerosis Pathogenesis. J of Med Sci, 10; 136-144.

Gareus R, Kotsaki E, Xanthoulea S, van der Made I, Gijbels MJ, Kardakaris R, Polykratis A, Kollias G, de Winther MP, Pasparakis M. (2008). Endothelial cell-specific NFkappaB inhibition protects mice from atherosclerosis. Cell Metab.; 8(5):372-83.

Gey KF and Puska P. (1989). Plasma vitamins E and A inversely correlated to mortality from ischemic heart disease in cross-cultural epidemiology. Ann N Y Acad Sci. 570:268-82.

Gokce N, Keaney JF Jr, Frei B, Holbrook M, Olesiak M, Zachariah BJ, Leeuwenburgh C, Heinecke JW, Vita JA (1999). Long-term ascorbic acid administration reverses endothelial vasomotor dysfunction in patients with coronary artery disease. Circulation. 99(25):3234-40.

Gu L, Okada Y, Clinton SK, Gerard C, Sukhova GK, Libby P, Rollins BJ. (1998). Absence of monocyte chemoattractant protein-1 reduces atherosclerosis in low density lipoprotein receptor-deficient mice. Mol Cell.;2(2):275-81.

Haker, A., Harlan, M., Ross, R. (1983). Effect of sulfinpyrozone on homocysteine- induced endothelial injury and arteriosclerosis in baboons. Circ. Res., 53: 731-739.

Halliwell B (2009). The wanderings of a free radical. Free Radic Biol Med, Mar 1;46(5):531-42.

Heller R, Münscher-Paulig F, Gräbner R, Till U (1999). L-Ascorbic acid potentiates nitric oxide synthesis in endothelial cells. J Biol Chem.274(12):8254-60.

Holvoet P, Lee DH, Steffes M, Gross M, Jacobs DR Jr.(2008). Association between circulating oxidized low-density lipoprotein and incidence of the metabolic syndrome. JAMA.299(19):2287-93.

Honarbakshsh S and Schachter M. (2009). Vitamins and cardiovascular disease. British Journal of Nutrition. 101,1113-1131.

Hulsmans M, De Keyzer D, Holvoet P. (2011). MicroRNAs regulating oxidative stress and inflammation in relation to obesity and atherosclerosis. FASEB J. ;25(8):2515-27.

Hulthe J and Fagerberg B. (2002). Circulating oxidized LDL is associated with subclinical atherosclerosis development and inflammatory cytokines (AIR Study). Arterioscler Thromb Vasc Biol.;22(7):1162-7.

Ikeda, H., Koga, Y., Oda, T. (1994). Free Oxygen radicals contribute to platelets aggregation and cyclic flow variations in stenosed and endothelium-injured canine coronary arteries. J. Am. Coll. Cardiol., 24: 1749-1756.

Imai H.; Nakagawa Y. (2003) Biological significance of phospholipid hydroperoxide glutathione peroxidase (PHGPx, GPx4) inmammalian cells. Free Radic. Biol. Med. 34: $145-169$.

Islam KN, Devraj S \& Jialal I (1998). Alfa-tocopherol enrichment of monocytes decreases agonist-induced adhesion to human endothelial cells. Circulation; 98,2255-2261.

Itabe H, Ueda M. (2007). Measurement of plasma oxidized low-density lipoprotein and its clinical implications. J Atheroscler Thromb.;14(1):1-11.

Jialal I \& Grundy SM (1991). Preservation of the endogenous anti-oxidants in low density lipoprotein by ascorbate but not probucol during oxidative modification. J Clin Invest 87,597-601. 
Jourdan, A., Aguejouf, O., Imbault, P. (1995). Experimental thrombosis model induced by free radicals. Application to aspirin and other different substances. Thromb. Res., 129: 109-112.

Kagan VE, Serbinova EA, Forte T, Scita G, Packer L (1992). Recycling of vitamin E in human low density lipoproteins. J Lipid Res.;33(3):385-97.

Karin, K., and Robert, K. (1993). Oxygen radical scavenging agents as adjuvant therapy with tissue plasminogen activator in a canine model of coronary thrombolysis. Cardiov. Res., 27: 925-934.

Kirk EA, Dinauer MC, Rosen H, Chait A, Heinecke JW, LeBoeuf RC. (2000). Impaired superoxide production due to a deficiency in phagocyte NADPH oxidase fails to inhibit atherosclerosis in mice. Arterioscler Thromb Vasc Biol.;20:1529 -1535.

Kotani K, Yamada S, Uurtuya S, Yamada T, Taniguchi N, Sakurabayashi I. (2010 ).The association between blood glucose and oxidized lipoprotein(a) in healthy young women. Lipids Health Dis.;9:103.

Lee CF, Qiao M, Schröder K, Zhao Q, Asmis R. (2010). Nox4 is a novel inducible source of reactive oxygen species in monocytes and macrophages and mediatesoxidized low density lipoprotein-induced macrophage death. Circ Res;106(9):1489-97.

Levine, H., Sladdin, D., Krinsky, I. (1981). Superoxide Xanthine oxidase and platelet reactions further studies on mechanism by which oxidants influence platelets. Thromb. Haemost., 45: 290-293.

Lewis MJ, Malik TH, Ehrenstein MR, Boyle JJ, Botto M, Haskard DO. (2009). Immunoglobulin $\mathrm{M}$ is required for protection against atherosclerosis in low-density lipoprotein receptor-deficient mice. Circulation.;120(5):417-26.

Li D, Mehta JL. (2000). Antisense to LOX-1 inhibits oxidized LDL-mediated upregulation of monocyte chemoattractant protein-1 and monocyte adhesion to human coronary artery endothelial cells. Circulation.;101(25):2889-95.

Liu S, Beckman JS, Ku DD. (1994). Peroxynitrite, a product of superoxide and nitric oxide, produces coronary vasorelaxation in dogs. J Pharmacol Exp Ther.;268(3):1114-21.

Mabile L, Bruckdorfer KR, Rice-Evans C. (1999). Moderate supplementation with natural alpha tocopherol decreases platelet aggregation and low density lipoprotein oxidation. Atherosclerosis, 147:177-185.

Macfarlane, D., Sheila, G., Carol, L. Mills, B. (1977). Malondialdehyde Production by Platelets during secondary aggregation. Thrombos. Haemostas. (Stuttg.), 38: 1002-1009.

Madrau MA, Piscopo A, Sanguinetti AM, Del Caro A, Poiana M, Romeo FV and Piga A.(2009). Effect of drying temperature on polyphenolic content and antioxidant activity of apricots. European food research and technology. 228, 441-448

Malmgren, R., Unge, G., Zetterstrom, O. (1990). Lowered platelet glutathione peroxidase activity in patients with intrinsic asthma. Allergy, 45: 523-527.

Marie, J. (1979). Platelet malonyldialdehyde formation: An indicator of platelet hyperfunction. Thrombos. Haemostas. (Stuttg.), 42: 549-654.

Marklund, L., Holme, E., Hellner, L. (1982). Superoxide dismutase in extracellular fluids. Clin. Chim. Acta., 126: 41-51.

Martin KR (2010). The bioactive agent ergothioneine, a key component of dietary mushrooms, inhibits monocyte binding to endothelial cells characteristic of early cardiovascular disease. J Med Food.;13(6):1340-6.

Mehta JL, Sanada N, Hu CP, Chen J, Dandapat A. Sugawara F, Satoh H, Inoue K, Kawase Y, Jishage K, Suzuki H, Takeya M, Schnackenberg L, Beger R, Hermonat PL, Thomas 
M, Sawamura T. (2007). Deletion of LOX-1 reduces atherogenesis in LDLR knockout mice fed high cholesterol diet. Circ Res;100(11):1634-42.

Meng, Y., Jeffrey, T., Una, S., Abendschein, R. (1995). Potentiation of endogenous nitric oxide with superoxide dismutase. Inhibits platelet-mediated thrombosis in injured and stenotic arteries. J. Am. Coll. Cardiol., 25: 269-275

Michiels C, Raes M, Toussaint O, Remacle J(1994). Importance of Se-glutathione peroxidase, catalase, and $\mathrm{Cu} / \mathrm{Zn}-\mathrm{SOD}$ for cell survival against oxidative stress. Free Radic Biol Med.;17(3):235-48.

Michio A., Junichi, F., Keiichiro, S., et al. (1995). Inactivation of glutathione peroxidase by nitric oxide. J. Biol. Chem., 270: 21035-21039.

Mitra S, Deshmukh A, Sachdeva R, Lu J, Mehta JL. (2011). Oxidized low-density lipoprotein and atherosclerosis implications in antioxidant therapy. Am J Med Sci.;342(2):135-42.

Moore KJ, Freeman MW. (2006). Scavenger receptors in atherosclerosis: beyond lipid uptake. Arterioscler Thromb Vasc Biol.;26(8):1702-11.

Naderi GA, Asgary S, Sarraf-Zadegan N and Shirvany H. (2003). Anti-oxidant effect of flavonoids on the susceptibility of LDL oxidation. Mol Cell Biochem. 246(1-2):193-6.

Nielsen, H. (1981). Covalent binding of peroxidized phospholipid to protein. III. Reaction of individual phospholipids with different proteins. Lipids, 16: 215.

Palinski W, Tangirala RK, Miller E, Young SG, Witztum JL. (1995). Increased autoantibody titers against epitopes of oxidized LDL in LDL receptor-deficient mice with increased atherosclerosis. Arterioscler Thromb Vasc Biol.;15(10):1569-76.

Palma JM, Corpas FJ, del Río LA (2009). Proteome of plant peroxisomes: new perspectives on the role of these organelles in cell biology. Proteomics. May;9(9):2301-12.

Parthasarathy S, Khan-Merchant N, Penumetcha M, Khan BV and Santanam N. (2001). Did the antioxidant trials fail to validate the oxidation hypothesis? Curr Atheroscler Rep.;3(5):392-8.

Parthasarathy S, Raghavamenon A, Garelnabi O, Santanam N. (2010). Oxidized low-density lipoprotein. Methods Mol Biol.;610:403-17.

Parthasarathy S., Litvinov D., Selvarajan K., Garelnabi M., (2008). Lipid peroxidation and decomposition - Conflicting roles in plaque vulnerability and stability. Biochimica et Biophysica Acta ;1781, 221-231

Patel R, Garg R, Erande S and B Maru G.(2007). Chemopreventive herbal anti-oxidants: current status and future perspectives. J Clin Biochem Nutr.;40(2):82-91.

Princen HM, van Duyvenvoorde W, Buytenhek R, van der Laarse A, van Poppel G, Gevers Leuven JA, van Hinsbergh VW.(1995). Supplementation with low doses of vitamin E protects LDL from lipid peroxidation in men and women. Arterioscler Thromb Vasc Biol.15(3):325-33.

Princen HM, van Poppel G, Vogelezang C, Buytenhek R, Kok FJ. (1992) Supplementation with vitamin $\mathrm{E}$ but not beta-carotene in vivo protects low density lipoprotein from lipid peroxidation in vitro. Effect of cigarette smoking. Arterioscler Thromb.;12(5):554-62.

Raghavamenon A, Garelnabi M, Babu S, Aldrich A, Litvinov D, Parthasarathy S. (2009). Alpha-tocopherol is ineffective in preventing the decomposition of preformed lipid peroxides and may promote the accumulation of toxic aldehydes: a potential explanation for the failure of antioxidants to affect human atherosclerosis. Antioxid Redox Signal.;11(6):1237-48.

Ramprasath VR, Jones PJ. (2010). Anti-atherogenic effects of resveratrol. Eur J Clin Nutr. 64(7):660-8. 
Rao VS, Nagaraj RK, Hebbagodi S, Kadarinarasimhiah NB, Kakkar VV.(2010).Association of Inflammatory and Oxidative Stress Markers with Metabolic Syndrome in Asian Indians in India. Cardiol Res Pract. ;2011:295976.

Rayment SJ, Shaw J, Woollard KJ, Lunec J, Griffiths HR (2003). Vitamin C supplementation in normal subjects reduces constitutive ICAM-1 expression. Biochem Biophys Res Commun. 308(2):339-45.

Rayment SJ, Shaw J, Woollard KJ, Lunec J, Griffiths HR (2003). Vitamin C supplementation in normal subjects reduces constitutive ICAM-1 expression. Biochem Biophys Res Commun.;308(2):339-45.

Rice-Evans CV, Nicholas Miller and George Pagangal. (1997). Antioxidant properties of phenolic compounds. Trends in Plant Science. 2,152-159.

Rimm EB, Stampfer MJ, Ascherio A, Giovannucci E, Colditz GA, Willett WC.(1993). Vitamin E consumption and the risk coronary heart disease in men. N Engl J Med; 328:14501456.

Roger, C., Tomm, B., Ling-Yi C., James C., et al., (1994). Superoxide and peroxynitrite in atherosclerosis, Proc. Natl. Acad. Sci. USA, 91: 1044-1048.

Ross R (1986). The Pathogenesis of atherosclerosis -an update. New Eng. J. Med., 314: 488-500.

Ross R (1993). The Pathogenesis of atherosclerosis : a perspective for the 1990s. Nature, 362: 801-809.

Rössig L, Hoffmann J, Hugel B, Mallat Z, Haase A, Freyssinet JM, Tedgui A, Aicher A, Zeiher AM, Dimmeler S (2001). Vitamin C inhibits endothelial cell apoptosis in congestive heart failure. Circulation. ;104(18):2182-7.

Scheffer PG, Bos G, Volwater HG, Dekker JM, Heine RJ, Teerlink T.(2003).Associations of LDL size with in vitro oxidizability and plasma levels of in vivo oxidized LDL in Type 2 diabetic patients. Diabet Med. 20(7):563-7.

Shargorodsky M, Debby O, Matas Z, Zimlichman R (2010). Effect of long-term treatment with antioxidants (vitamin C, vitamin E, coenzyme Q10 and selenium) on arterial compliance, humoral factors and inflammatory markers in patients with multiple cardiovascular risk factors. Nutr Metab (Lond). ;7:55.

Shoenfeld Y, Wu R, Dearing LD, Matsuura E. (2004). Are anti-oxidized low-density lipoprotein antibodies pathogenic or protective? Circulation.;110(17):2552-8.

Sperandio M, Smith ML, Forlow SB, Olson TS, Xia L, McEver RP, Ley K. (2003). P-selectin glycoprotein ligand-1 mediates L-selectin-dependent leukocyte rolling in venules. J Exp Med.; 197: 1355-1363.

Stampher MJ, Hennekens CH, Manson JE, Colditz GA, Rosner B, Willett WC.(1993). Vitamin $\mathrm{E}$ consumption and the risk coronary heart disease in women. $N$ Engl J Med; 328:1444-1449.

Stein S, Lohmann C, Schäfer N, Hofmann J, Rohrer L, Besler C, Rothgiesser KM, Becher B, Hottiger MO, Borén J, McBurney MW, Landmesser U, Lüscher TF, Matter CM. (2010). SIRT1 decreases Lox-1-mediated foam cell formation in atherogenesis. Eur Heart J.;31(18):2301-9.

Steinberg D, Parthasarathy S, Carew TE, Khoo JC, Witztum JL. (1989). Beyond cholesterol. Modifications of low-density lipoprotein that increase its atherogenicity. $\mathrm{N} \mathrm{Engl} \mathrm{J}$ Med.;320(14):915-24.

Tanigawa H, Miura S, Matsuo Y, Fujino M, Sawamura T, Saku K. (2006). Dominant-negative lox-1 blocks homodimerization of wild-type lox-1-induced cell proliferation through extracellular signal regulated kinase 1/2 activation. Hypertension.;48(2):294-300. 
Tanner, C., Noll, G., Boulanger, M., Luscher, F. (1990). Oxidized low density lipoproteins inhibit relaxations of porcine coronary arteries : role of scavenger receptor and endothelium-derived nitric oxide. Circulation, 83: 2012-2020.

Tsimikas S, Brilakis ES, Lennon RJ, Miller ER, Witztum JL, McConnell JP, Kornman KS, Berger PB. (2007). Relationship of IgG and IgM autoantibodies to oxidized low density lipoprotein with coronary artery disease and cardiovascular events. J Lipid Res.;48(2):425-33.

Tsuzura S, Ikeda Y, Suehiro T, Ota K, Osaki F, Arii K, Kumon Y and Hashimoto K. (2004).Correlation of plasma oxidized low-density lipoprotein levels to vascular complications and human serum paraoxonase in patients with type 2 diabetes. Metabolism. 53(3):297-302.

Ursini F, Maiorino M, Valente M, Ferri L, Gregolin C. (1982) Purification from pig liver of a protein which protects liposomes and biomembranes from peroxidative degradation and exhibits glutathione peroxidase activity on phosphatidylcholine hydroperoxides. Biochim Biophys Acta. 710:197-211

Violi, F., Iuliano, L. Alessandri, C., Ghiselli, A., Balsano, F. (1985). A simple method for evaluating platelet superoxide dismutase. Scand. J. Clin. Lab. Invest., 45: 713-716.

von Eckardstein A, Rohrer L. (2009). Transendothelial lipoprotein transport and regulation of endothelial permeability and integrity by lipoproteins. Curr Opin Lipidol. 20(3):197-205.

Wesiger, R., Fridovich, I. (1973). Superoxide dismutase organelle specificity. J. Biol. Chem., 248: 358-392.

Wongcharoen W and Phrommintikul A. (2009).The protective role of curcumin in cardiovascular diseases. Int J Cardiol. 133(2):145-51.

Woodman OL and Chan ECh. (2004). Vascular and anti-oxidant actions of flavonols and flavones. Clin Exp Pharmacol Physiol. 31(11):786-90.

World Health Organization WHO, Tech. Rep. Serv., (1985). 1453: 1-20.

Yagi K.; Komura S.; Kojima H.; Sun Q.; Nagata N.; Ohishi N.; Nishikimi M. (1996) Expression of human phospholipid hydroperoxide glutathione peroxidase gene for protection of host cells from lipid hydroperoxide-mediated injury. Biochem. Biophys. Res. Commun. 219: 486-491.

Yang J, Hirata T, Croce K, Merrill-Skoloff G, Tchernychev B, Williams E, Flaumenhaft R, Furie BC, Furie B. (1999).Targeted gene disruption demonstrates that P-selectin glycoprotein ligand 1 (PSGL-1) is required for P-selectin-mediated but not Eselectin-mediated neutrophil rolling and migration. J Exp Med.; 190: 1769-1782.

Yang MY, Huang CN, Chan KC, Yang YS, Peng CH, Wang CJ. (2011( Mulberry leaf polyphenols possess antiatherogenesis effect via inhibiting LDL oxidation and foam cell formation. J Agric Food Chem. 9;59(5):1985-95.

Yusuf S, Dagenais G, Pogue J, Bosch J and Sleight P. (2000). Vitamin E supplementation and cardiovascular events in high risk patients. The Heart Outomes prevention evaluation study Investigators. N Engl J Med. 342;154-160.

Zapolska-Downar D, Zapolski-Downar A, Markiewski M (2000). Slective inhibition by alpha-tocopherol of vascular cell adhesion molecule-1 expression in human endothelial cells. Biochem Biophys Res Commun 274, 609-615.

Zhang W, Salomon RG. (2005). Oxidized phospholipids, isolevuglandins, and atherosclerosis. Mol Nutr Food Res.;49(11):1050-62. 


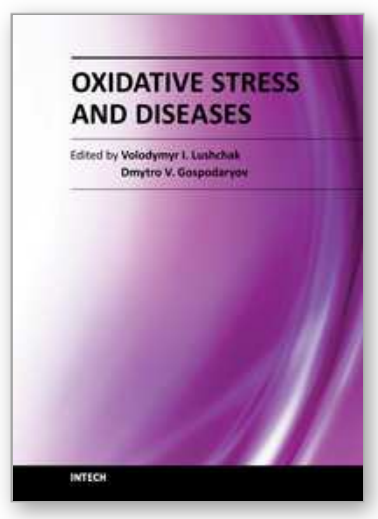

\author{
Oxidative Stress and Diseases \\ Edited by Dr. Volodymyr Lushchak
}

ISBN 978-953-51-0552-7

Hard cover, 610 pages

Publisher InTech

Published online 25, April, 2012

Published in print edition April, 2012

The development of hypothesis of oxidative stress in the 1980s stimulated the interest of biological and biomedical sciences that extends to this day. The contributions in this book provide the reader with the knowledge accumulated to date on the involvement of reactive oxygen species in different pathologies in humans and animals. The chapters are organized into sections based on specific groups of pathologies such as cardiovascular diseases, diabetes, cancer, neuronal, hormonal, and systemic ones. A special section highlights potential of antioxidants to protect organisms against deleterious effects of reactive species. This book should appeal to many researchers, who should find its information useful for advancing their fields.

\title{
How to reference
}

In order to correctly reference this scholarly work, feel free to copy and paste the following:

Mahdi Garelnabi, Srikanth Kakumanu and Dmitry Litvinov (2012). Role of Oxidized Lipids in Atherosclerosis, Oxidative Stress and Diseases, Dr. Volodymyr Lushchak (Ed.), ISBN: 978-953-51-0552-7, InTech, Available from: http://www.intechopen.com/books/oxidative-stress-and-diseases/role-of-oxidized-lipids-in-atherosclerosis

\section{INTECH}

open science | open minds

\section{InTech Europe}

University Campus STeP Ri

Slavka Krautzeka 83/A

51000 Rijeka, Croatia

Phone: +385 (51) 770447

Fax: +385 (51) 686166

www.intechopen.com

\section{InTech China}

Unit 405, Office Block, Hotel Equatorial Shanghai

No.65, Yan An Road (West), Shanghai, 200040, China

中国上海市延安西路65号上海国际贵都大饭店办公楼 405 单元

Phone: +86-21-62489820

Fax: +86-21-62489821 
(C) 2012 The Author(s). Licensee IntechOpen. This is an open access article distributed under the terms of the Creative Commons Attribution 3.0 License, which permits unrestricted use, distribution, and reproduction in any medium, provided the original work is properly cited. 